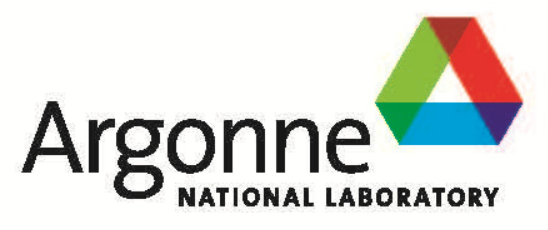

\title{
Corrosion Test Results for Construction Materials Used in Mini-SHINE System
}

Chemical Sciences and Engineering Division 


\begin{abstract}
About Argonne National Laboratory
Argonne is a U.S. Department of Energy laboratory managed by UChicago Argonne, LLC under contract DE-AC02-06CH11357. The Laboratory's main facility is outside Chicago, at 9700 South Cass Avenue, Argonne, Illinois 60439. For information about Argonne and its pioneering science and technology programs, see www.anl.gov.
\end{abstract}

\title{
DOCUMENT AVAILABILITY
}

Online Access: U.S. Department of Energy (DOE) reports produced after 1991 and a growing number of pre-1991 documents are available free via DOE's SciTech Connect (http://www.osti.gov/scitech/)

Reports not in digital format may be purchased by the public from the National Technical Information Service (NTIS):

U.S. Department of Commerce

National Technical Information Service

5301 Shawnee Rd

Alexandra, VA 22312

unw.ntis.gov

Phone: (800) 553-NTIS (6847) or (703) 605-6000

Fax: (703) 605-6900

Email: orders@ntis.gov

Reports not in digital format are available to DOE and DOE contractors from the Office of Scientific and Technical Information (OST):

U.S. Department of Energy

Office of Scientific and Technical Information

P.O. Box 62

Oak Ridge, TN 37831-0062

unw.osti.gov

Phone: (865) 576-8401

Fax: (865) 576-5728

Email: reports@osti.gov

\begin{abstract}
Disclaimer
This report was prepared as an account of work sponsored by an agency of the United States Government. Neither the United States Government nor any agency thereof, nor UChicago Argonne, LLC, nor any of their employees or officers, makes any warranty, express or implied, or assumes any legal liability or responsibility for the accuracy, completeness, or usefulness of any information, apparatus, product, or process disclosed, or represents that its use would not infringe privately owned rights. Reference herein to any specific commercial product, process, or service by trade name, trademark, manufacturer, or otherwise, does not necessarily constitute or imply its endorsement, recommendation, or favoring by the United States Government or any agency thereof. The views and opinions of document authors expressed herein do not necessarily state or reflect those of the United States Government or any agency thereof, Argonne National Laboratory, or UChicago Argonne, LLC.
\end{abstract}




\section{Corrosion Test Results for Construction Materials Used in Mini-SHINE System}

by

Amanda J. Youker, John F. Krebs, Yifen Tsai, and George F. Vandegrift

Chemical Sciences and Engineering Division, Argonne National Laboratory

prepared for

U.S. Department of Energy, National Nuclear Security Administration,

Office of Defense Nuclear Nonproliferation

May 2014 



\section{CONTENTS}

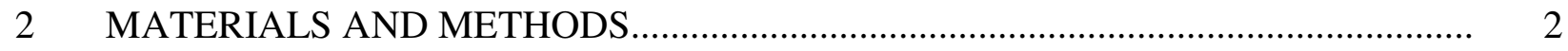

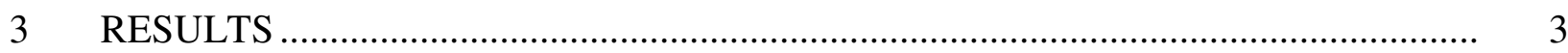

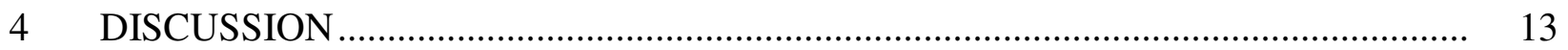

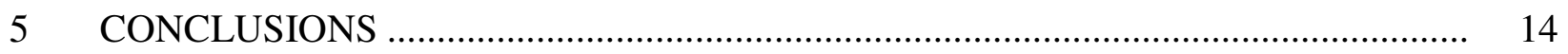

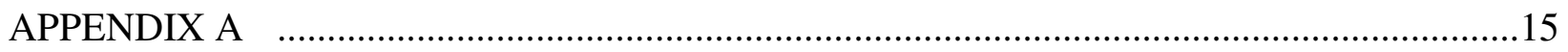

\section{FIGURES}

1 Estimated corrosion rates in units of $\mathrm{mm} / \mathrm{yr}$ for discs in contact with

$0.1 \mathrm{M} \mathrm{H}_{2} \mathrm{SO}_{4}$ at $60^{\circ} \mathrm{C}$ and $80^{\circ} \mathrm{C}$

2 Estimated corrosion rates in units of $\mathrm{mm} / \mathrm{yr}$ for discs in contact with $0.55 \mathrm{M} \mathrm{NaHSO}_{4}$ at $60^{\circ} \mathrm{C}$ and $80^{\circ} \mathrm{C}$

3 Estimated corrosion rates in units of $\mathrm{mm} / \mathrm{yr}$ for discs in contact with $140 \mathrm{~g}-\mathrm{U} / \mathrm{L} \mathrm{UO}_{2} \mathrm{SO}_{4}$ at $60^{\circ} \mathrm{C}$ and $80^{\circ} \mathrm{C}$

4 Estimated corrosion rates in units of mil/yr for discs in contact with $0.1 \mathrm{M} \mathrm{H}_{2} \mathrm{SO}_{4}$ at $60^{\circ} \mathrm{C}$ and $80^{\circ} \mathrm{C}$

5 Estimated corrosion rates in units of mil/yr for discs in contact with $0.55 \mathrm{M} \mathrm{NaHSO}_{4}$ at $60^{\circ} \mathrm{C}$ and $80^{\circ} \mathrm{C}$

6 Estimated corrosion rates in units of mil/yr for discs in contact with

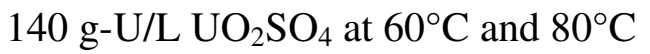

7 Iron Concentration in Various Solutions after Contact with 304SS Discs for $0.25-30$ Days at $60^{\circ} \mathrm{C}$ and $80^{\circ} \mathrm{C}$

8 Iron Concentration in Various Solutions after Contact with 316 SS Discs for $0.25-30$ Days at $60^{\circ} \mathrm{C}$ and $80^{\circ} \mathrm{C}$

9 Iron concentration in various solutions after contact with 2205SS Discs for $0.25-30$ days at $60^{\circ} \mathrm{C}$ and $80^{\circ} \mathrm{C}$ 


\section{FIGURES (Cont.)}

10 Titanium Concentration in Various Solutions after Contact with Ti Discs for $0.25-30$ Days at $60^{\circ} \mathrm{C}$ and $80^{\circ} \mathrm{C}$

11 Iron Concentration in $0.1 \mathrm{M} \mathrm{H}_{2} \mathrm{SO}_{4}$ Solution after Contact with $\mathrm{SS}$ and Ti Discs for $0.25-30$ Days at $60^{\circ} \mathrm{C}$

12 Iron Concentration in $0.1 \mathrm{M} \mathrm{H}_{2} \mathrm{SO}_{4}$ Solution after Contact with SS and Ti Discs for $0.25-30$ Days at $80^{\circ} \mathrm{C}$

13 Iron Concentration in $0.55 \mathrm{M} \mathrm{NaHSO}_{4}$ Solution after Contact with $\mathrm{SS}$ and Ti Discs for $0.25-30$ Days at $60^{\circ} \mathrm{C}$

14 Iron Concentration in $0.55 \mathrm{M} \mathrm{NaHSO}_{4}$ Solution after Contact with $\mathrm{SS}$ and Ti for $0.25-30$ Days at $80^{\circ} \mathrm{C}$

15 Iron Concentration in $140 \mathrm{~g}-\mathrm{U} / \mathrm{L} \mathrm{UO}_{2} \mathrm{SO}_{4}$ Solution after Contact with SS and Ti Discs for $0.25-30$ days at $60^{\circ} \mathrm{C}$

16 Iron Concentration in $140 \mathrm{~g}-\mathrm{U} / \mathrm{L} \mathrm{UO}_{2} \mathrm{SO}_{4}$ solution after contact with $\mathrm{SS}$ and Ti Discs for $0.25-30$ days at $80^{\circ} \mathrm{C}$

\section{TABLES}

1 Data for Discs in Contact with $0.1 \mathrm{M} \mathrm{H}_{2} \mathrm{SO}_{4}$ at $60^{\circ} \mathrm{C}$ and $80^{\circ} \mathrm{C}$

2 Data for Discs in Contact with $0.1 \mathrm{M} \mathrm{NaHSO}_{4}$ at $60^{\circ} \mathrm{C}$ and $80^{\circ} \mathrm{C}$

3 Data for Discs in Contact with $140 \mathrm{~g}-\mathrm{U} / \mathrm{L} \mathrm{UO}_{2} \mathrm{SO}_{4}$ at $60^{\circ} \mathrm{C}$ and $80^{\circ} \mathrm{C}$ 


\section{CORROSION TEST RESULTS FOR CONSTRUCTION MATERIALS USED IN MINI-SHINE SYSTEM}

\section{INTRODUCTION}

To satisfy Argonne safety requirements, we are using sodium bisulfate as a surrogate for uranyl sulfate during irradiation tests at the linac prior to conducting experiments with uranyl sulfate. After passing a $0.55 \mathrm{M} \mathrm{NaHSO}_{4} / 0.1 \mathrm{M} \mathrm{H}_{2} \mathrm{SO}_{4}(\mathrm{pH}$ 1) solution through the target solution vessel and stainless-steel tubing, valves, and pump as part of the mini-SHINE experimental setup at the linac, the solution turned blue. The blue color intensified when the system temperature reached $80^{\circ} \mathrm{C}$. The tubing and target solution vessel are made of 304SS, and all other components are made of $316 \mathrm{SS}$. As a result, corrosion tests were performed using 304SS and 316SS in contact with $\mathrm{H}_{2} \mathrm{O}, 0.1 \mathrm{M} \mathrm{H}_{2} \mathrm{SO}_{4}, 0.55 \mathrm{M} \mathrm{NaHSO}_{4}$, and $140 \mathrm{~g}-\mathrm{U} / \mathrm{L} \mathrm{UO}_{2} \mathrm{SO}_{4}$ for 6 hours, 24 hours, 5 days, 10 days, and 30 days at $60^{\circ} \mathrm{C}$ and $80^{\circ} \mathrm{C}$. Corrosion-rate data were required to ensure the sodium bisulfate, sulfuric acid $(\mathrm{pH}=1)$, and uranyl sulfate $(140 \mathrm{~g}-\mathrm{U} / \mathrm{L})$ solutions would not corrode the components of the mini-SHINE setup to any great extent. Also subjected to these tests were 2205SS and Ti metal. The 2205SS was tested because it is similar to 2304SS, which is currently being tested at Oak Ridge National Laboratory. Oak Ridge is doing a more thorough set of corrosion tests for SHINE Medical Technologies. Titanium metal was tested as a blank to ensure metals such as $\mathrm{Fe}, \mathrm{Ni}$, and $\mathrm{Cr}$ did not stick to the discs that were made with a stainless steel punch. 


\section{MATERIALS AND METHODS}

Discs (0.25-inch outer diameter) were cut from 1/16-inch-thick sheets of 304SS, 316SS, 2205SS, and Ti. Each metal disc was rinsed with ethanol to remove manufacturing oils and allowed to dry at room temperature. Each disc was placed in a test tube with a solution containing $4 \mathrm{~mL}$ of $\mathrm{H}_{2} \mathrm{O}, 0.1 \mathrm{M} \mathrm{H}_{2} \mathrm{SO}_{4}, 0.55 \mathrm{M} \mathrm{NaHSO}_{4}$, or $140 \mathrm{~g}-\mathrm{U} / \mathrm{L} \mathrm{UO}_{2} \mathrm{SO}_{4}(\mathrm{pH}=1)$. The tubes were covered by a vented slip-on cap. Samples were kept at $60^{\circ} \mathrm{C}$ and $80^{\circ} \mathrm{C}$ using thermostated baths (unit 1 - Thermo Scientific Model 2870 and unit 2 - Thermo-Haake Model SWB25, both with a 120 tube capacity) for 6 hours, 24 hours, 5 days, 10 days, and 30 days. After each time period, discs were removed from the test tube, washed with water, dried, and weighed to determine the corrosion rates based on changes in mass. Significant water losses occurred in the samples left at $60^{\circ} \mathrm{C}$ and $80^{\circ} \mathrm{C}$ for 30 days, so makeup water was added to the remaining solution after 30 days but before solutions were submitted for analyses. All solutions were submitted for inductively coupled plasma-mass spectroscopy (ICP-MS) analyses to determine the concentration of $\mathrm{Fe}, \mathrm{Ni}, \mathrm{Cr}$, and $\mathrm{Ti}$ after contact with each metal disc. 


\section{RESULTS}

Figures 1-3 show estimated corrosion rates in units of mm/year, and Figures 4-6 show estimated corrosion rates in units of mil/year for discs in contact with $0.1 \mathrm{M} \mathrm{H}_{2} \mathrm{SO}_{4}$, $0.55 \mathrm{M} \mathrm{NaHSO}_{4}$, and $140 \mathrm{~g}-\mathrm{U} / \mathrm{L} \mathrm{UO}_{2} \mathrm{SO}_{4}$. (These data are also given in tabular form in the appendix.) These corrosion rates show high initial values that eventually level off, indicating that a passivation layer has formed. However, the reported corrosion rates should be considered as estimates, as non-ASTM approved methods and techniques were employed in this study. The ICP-MS data agree with the estimated corrosion rates in that the $\mathrm{Fe}, \mathrm{Ni}$, and $\mathrm{Cr}$ concentrations did not increase to any great extent after initial corrosion was observed in the first 6-24 hours.

In general, the discs in contact with $0.1 \mathrm{M} \mathrm{H}_{2} \mathrm{SO}_{4}$ (Figures 1 and 4) have lower estimated corrosion rates than the discs that were contacted with $0.55 \mathrm{M} \mathrm{NaHSO}_{4}$ (Figures 2 and 5) and $140 \mathrm{~g}-\mathrm{U} / \mathrm{L} \mathrm{UO}_{2} \mathrm{SO}_{4}$ (Figures 3 and 6). The 316SS samples show the highest initial corrosion rates after 6 and 24 hours of contact with $0.1 \mathrm{M} \mathrm{H}_{2} \mathrm{SO}_{4}$ (Figures 1 and 4); however, after 10 days, the estimated corrosion rates decrease significantly. Estimated corrosion rates for all samples in contact with $0.1 \mathrm{M} \mathrm{H}_{2} \mathrm{SO}_{4}$ become negligible after 10 days. Sodium bisulfate is the most corrosive solution as it has the highest concentration of free sulfate. Titanium metal is most affected by $0.55 \mathrm{M} \mathrm{NaHSO}_{4}$ (Figures 2 and 5) where corrosion rates at $80^{\circ} \mathrm{C}$ do not fall below $3 \mathrm{~mm} / \mathrm{yr}(\sim 0.12 \mathrm{mil} / \mathrm{yr})$. Both $304 \mathrm{SS}$ and $316 \mathrm{SS}$ show corrosion rates at $80^{\circ} \mathrm{C}$ of $1-1.2 \mathrm{~mm} / \mathrm{yr}$ $(\sim 0.5 \mathrm{mil} / \mathrm{yr})$ after contact with $0.55 \mathrm{M} \mathrm{NaHSO}_{4}$, but those rates decrease to $0.5 \mathrm{~mm} / \mathrm{yr}$ $(\sim 0.02 \mathrm{mil} / \mathrm{yr})$ after 30 days. Uranyl sulfate is slightly more corrosive than $0.1 \mathrm{M} \mathrm{H}_{2} \mathrm{SO}_{4}$, but corrosion rates are below $0.05 \mathrm{~mm} / \mathrm{yr}(0.02 \mathrm{mil} / \mathrm{yr})$ for all discs after 30 days (Figures 3 and 6).

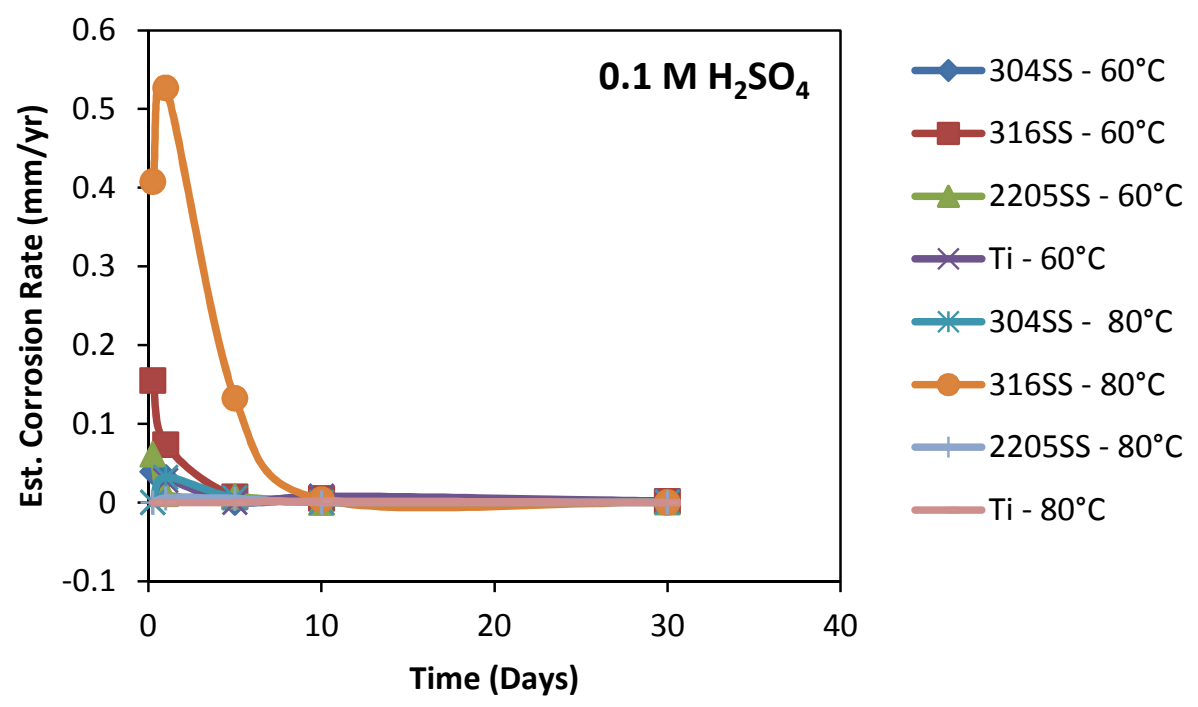

FIGURE 1 Estimated corrosion rates in units of $\mathrm{mm} / \mathrm{yr}$ for discs in contact with $0.1 \mathrm{M} \mathrm{H}_{2} \mathrm{SO}_{4}$ at $60^{\circ} \mathrm{C}$ and $80^{\circ} \mathrm{C}$ 


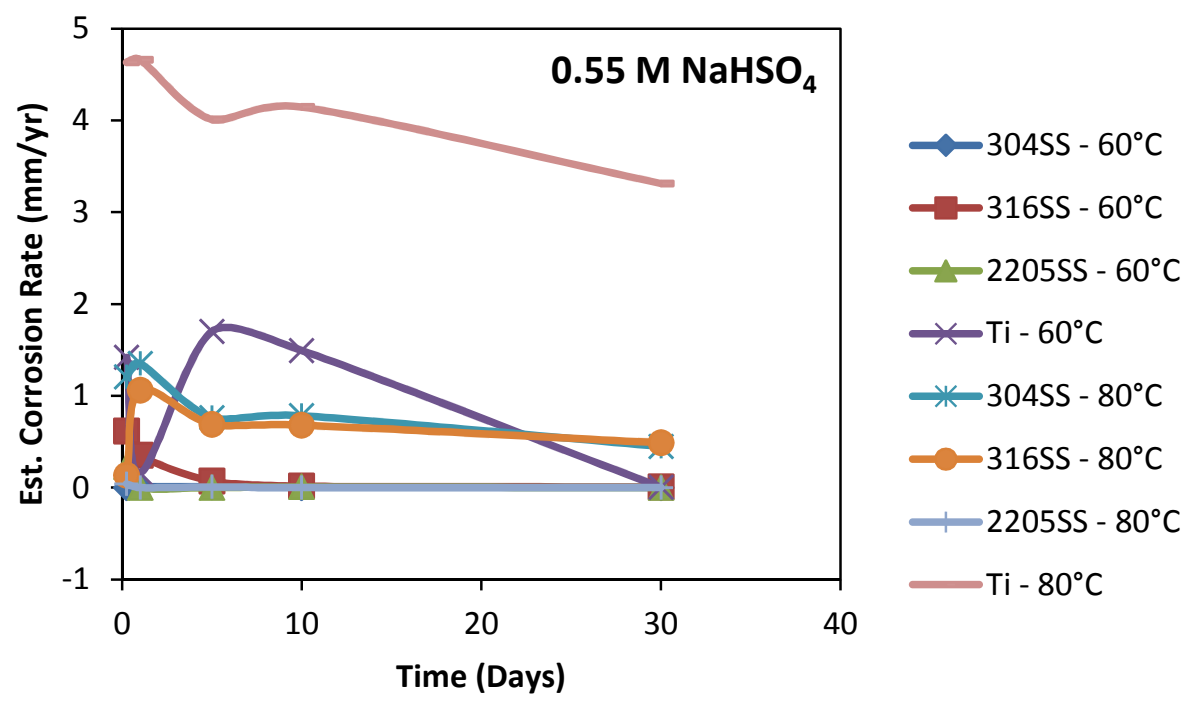

FIGURE 2 Estimated corrosion rates in units of $\mathbf{m m} / \mathbf{y r}$ for discs in contact with $0.55 \mathrm{M} \mathrm{NaHSO}_{4}$ at $60^{\circ} \mathrm{C}$ and $80^{\circ} \mathrm{C}$

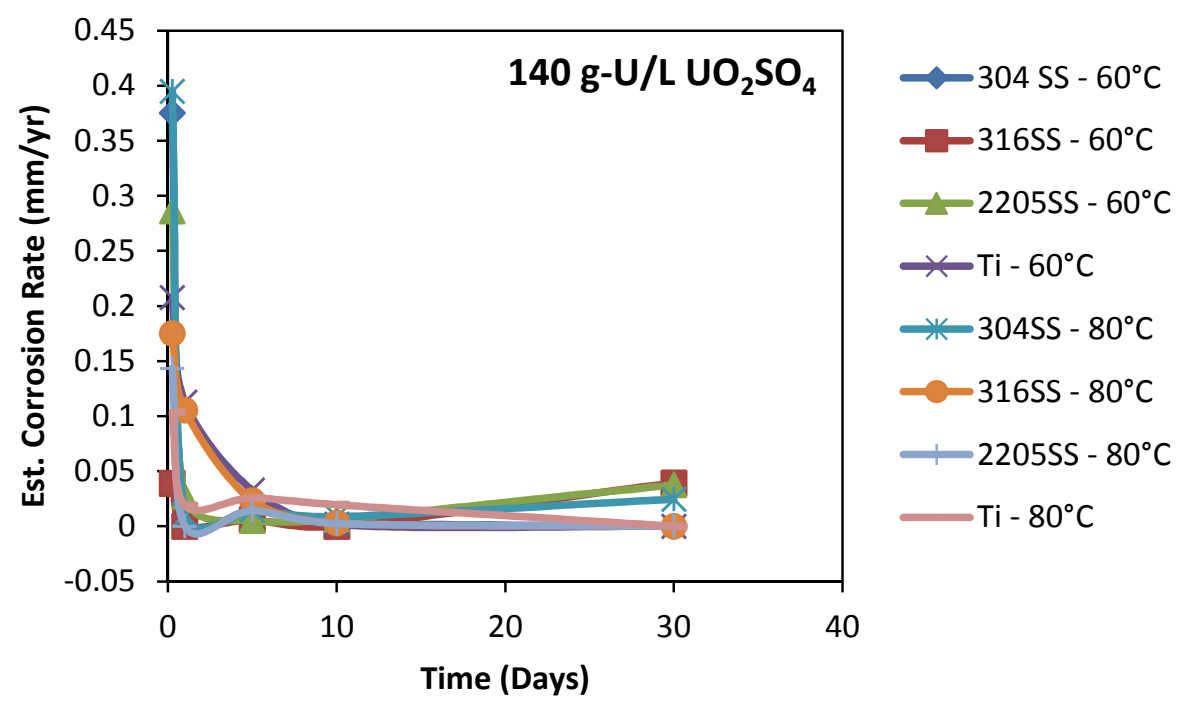

FIGURE 3 Estimated corrosion rates in units of $\mathbf{m m} / \mathbf{y r}$ for discs in contact with $140 \mathrm{~g}-\mathrm{U} / \mathrm{L} \mathrm{UO}_{2} \mathrm{SO}_{4}$ at $60^{\circ} \mathrm{C}$ and $80^{\circ} \mathrm{C}$ 


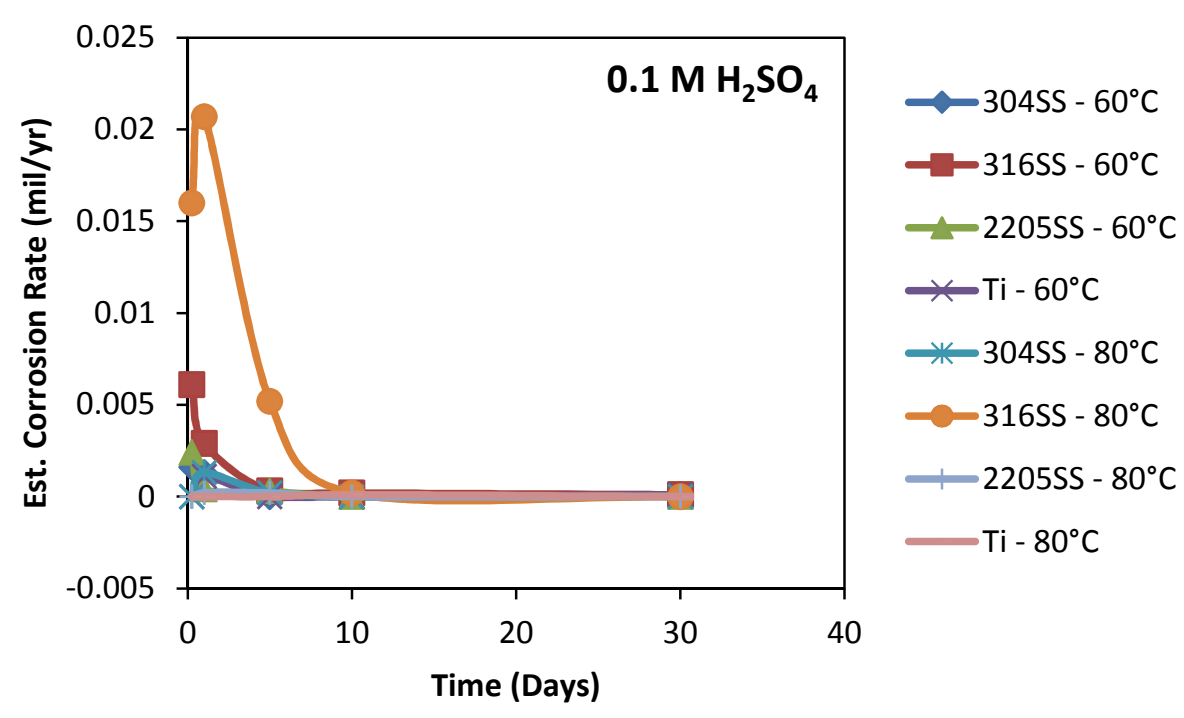

FIGURE 4 Estimated corrosion rates in units of $\mathrm{mil} / \mathrm{yr}$ for discs in contact with $0.1 \mathrm{M} \mathrm{H}_{2} \mathrm{SO}_{4}$ at $60^{\circ} \mathrm{C}$ and $80^{\circ} \mathrm{C}$

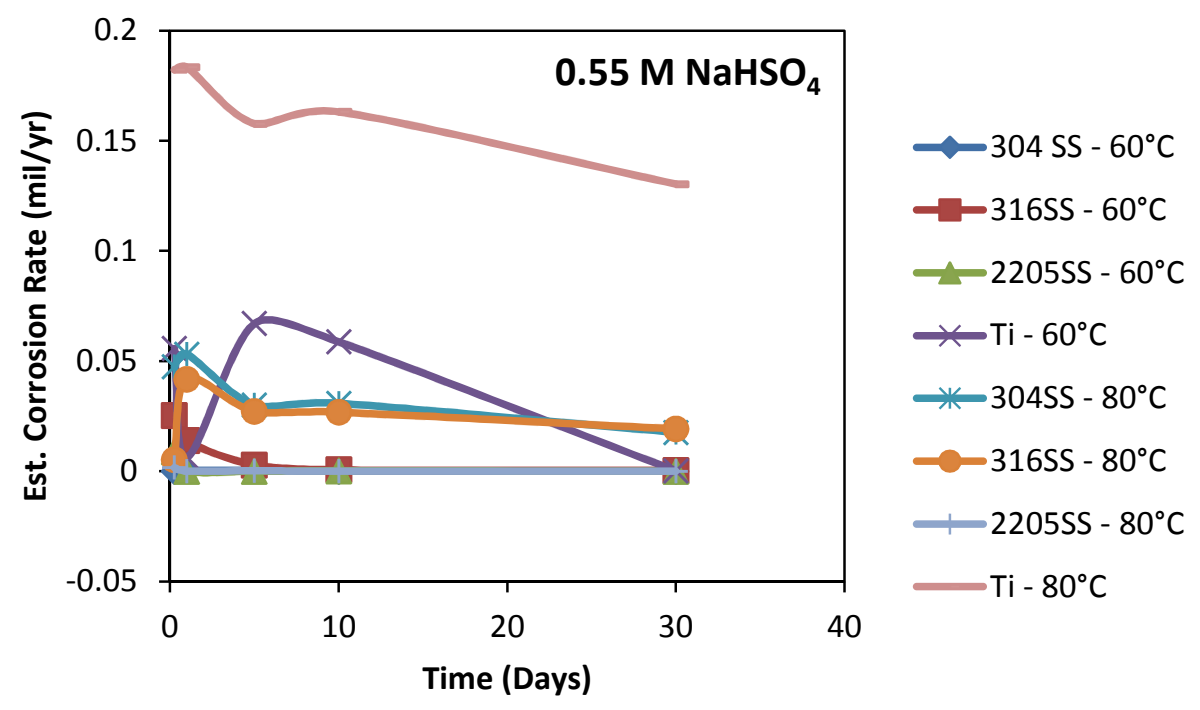

FIGURE 5 Estimated corrosion rates in units of mil/yr for discs in contact with $0.55 \mathrm{M} \mathrm{NaHSO}_{4}$ at $60^{\circ} \mathrm{C}$ and $80^{\circ} \mathrm{C}$ 


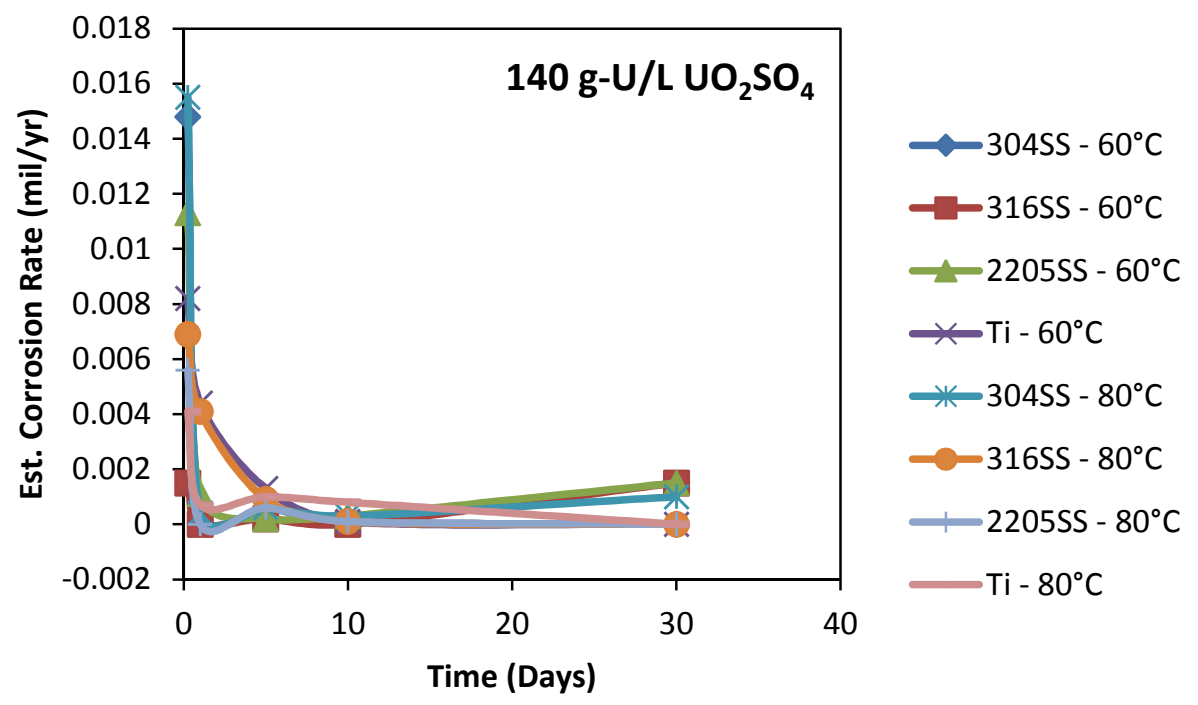

FIGURE 6 Estimated corrosion rates in units of mil/yr for discs in contact with $140 \mathrm{~g}-\mathrm{U} / \mathrm{L} \mathrm{UO}_{2} \mathrm{SO}_{4}$ at $60^{\circ} \mathrm{C}$ and $80^{\circ} \mathrm{C}$

Figure 7 shows the concentration of Fe present in all solutions after being in contact with $304 \mathrm{SS}$ discs for $0.25-30$ days at $60^{\circ} \mathrm{C}$ and $80^{\circ} \mathrm{C}$. Iron concentrations are the highest after contact with $\mathrm{NaHSO}_{4}$ at $80^{\circ} \mathrm{C}$ for periods greater than one day. After 10 days of contact in all solutions, the concentration of $\mathrm{Fe}$ did not increase to any great extent. For samples in contact with $\mathrm{UO}_{2} \mathrm{SO}_{4}$ solutions, the $\mathrm{Fe}$ concentration is only slightly higher at $80^{\circ} \mathrm{C}$ compared to $60^{\circ} \mathrm{C}$. Concentrations of Fe and Ti measured in the blank solutions before contact with the discs were subtracted from the ICP-MS values obtained after contact with the various solutions.

Figure 8 shows the concentration of Fe present in all solutions after being in contact with $316 \mathrm{SS}$ discs for $0.25-30$ days at $60^{\circ} \mathrm{C}$ and $80^{\circ} \mathrm{C}$. With sodium bisulfate at $80^{\circ} \mathrm{C}, \mathrm{Fe}$ concentration is the highest after contact with $316 \mathrm{SS}$, increasing rapidly in the first ten days then stabilizing. After 10 days of contact, the concentration of Fe does not increase significantly for all solutions except $0.1 \mathrm{M} \mathrm{H}_{2} \mathrm{SO}_{4}$ at $80^{\circ} \mathrm{C}$, in which the Fe concentration increases from 10 to 30 days, but decreases from 5 to 10 days. By contrast, the Fe concentration remains unchanged after extended contact with $0.1 \mathrm{M} \mathrm{H}_{2} \mathrm{SO}_{4}$ at $60^{\circ} \mathrm{C}$. For samples in contact with uranyl sulfate solutions, the concentration of $\mathrm{Fe}$ does not increase over the entire test period and is only slightly higher at $80^{\circ} \mathrm{C}$, which is consistent with the $304 \mathrm{SS}$ results.

Figure 9 shows the Fe concentration present in all solutions after being in contact with 2205SS discs for $0.25-30$ days at $60^{\circ} \mathrm{C}$ and $80^{\circ} \mathrm{C}$. The Fe concentration is the highest after contact with uranyl sulfate solutions at $60^{\circ} \mathrm{C}$ and $80^{\circ} \mathrm{C}$, but that is consistent with results obtained with $304 \mathrm{SS}$ and $316 \mathrm{SS}$, where the concentration is near $1 \times 10^{5} \mu \mathrm{g} / \mathrm{L} \mathrm{Fe}$. Because $2205 \mathrm{SS}$ is more robust than $304 \mathrm{SS}$ and $316 \mathrm{SS}$, it shows less corrosion in the presence of $\mathrm{pH} 1$ sulfuric acid and sodium bisulfate.

Figure 10 shows the concentration of Ti present in all solutions after being in contact with Ti discs for $0.25-30$ days at $60^{\circ} \mathrm{C}$ and $80^{\circ} \mathrm{C}$. The Ti concentration is the highest after 


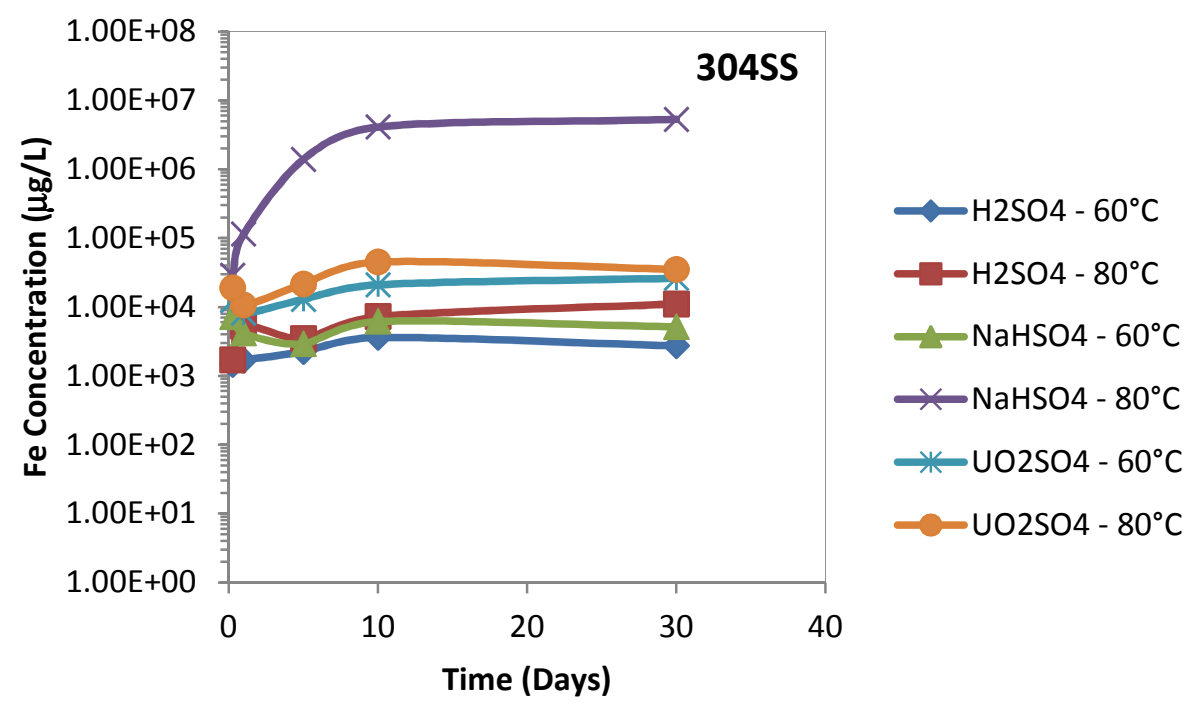

FIGURE 7 Iron Concentration in Various Solutions after Contact with 304SS Discs for $0.25-30$ Days at $60^{\circ} \mathrm{C}$ and $80^{\circ} \mathrm{C}$

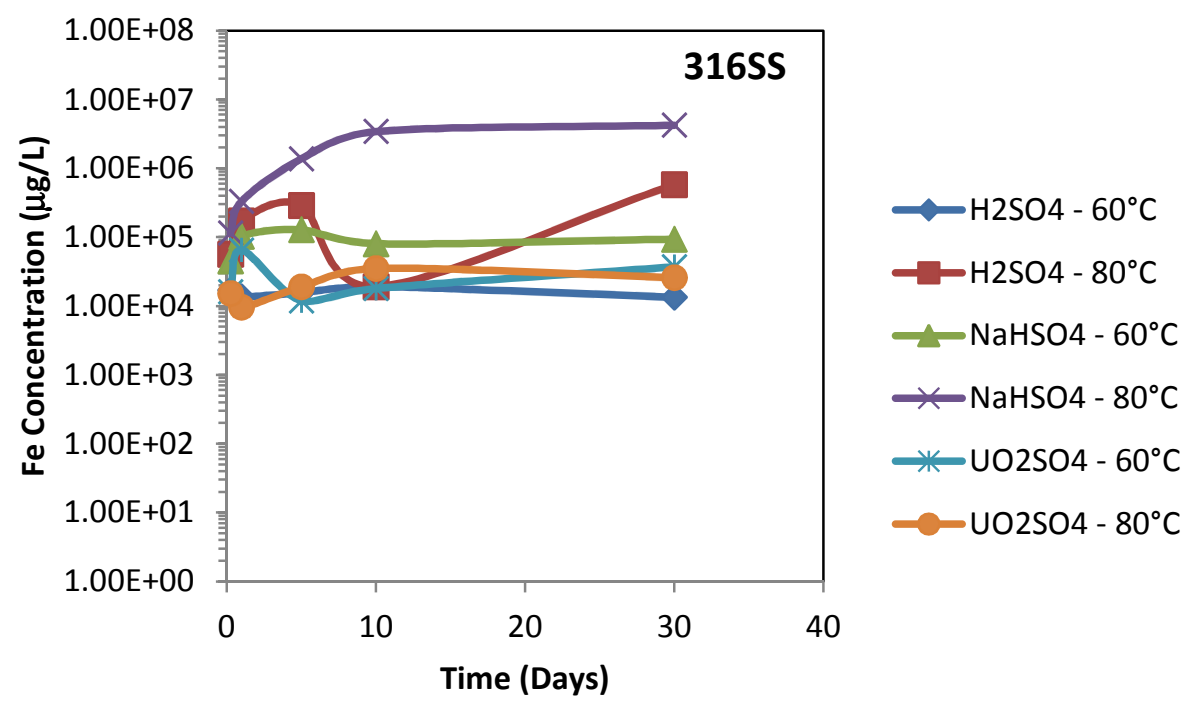

FIGURE 8 Iron Concentration in Various Solutions after Contact with 316SS Discs for $0.25-30$ Days at $60^{\circ} \mathrm{C}$ and $80^{\circ} \mathrm{C}$ 


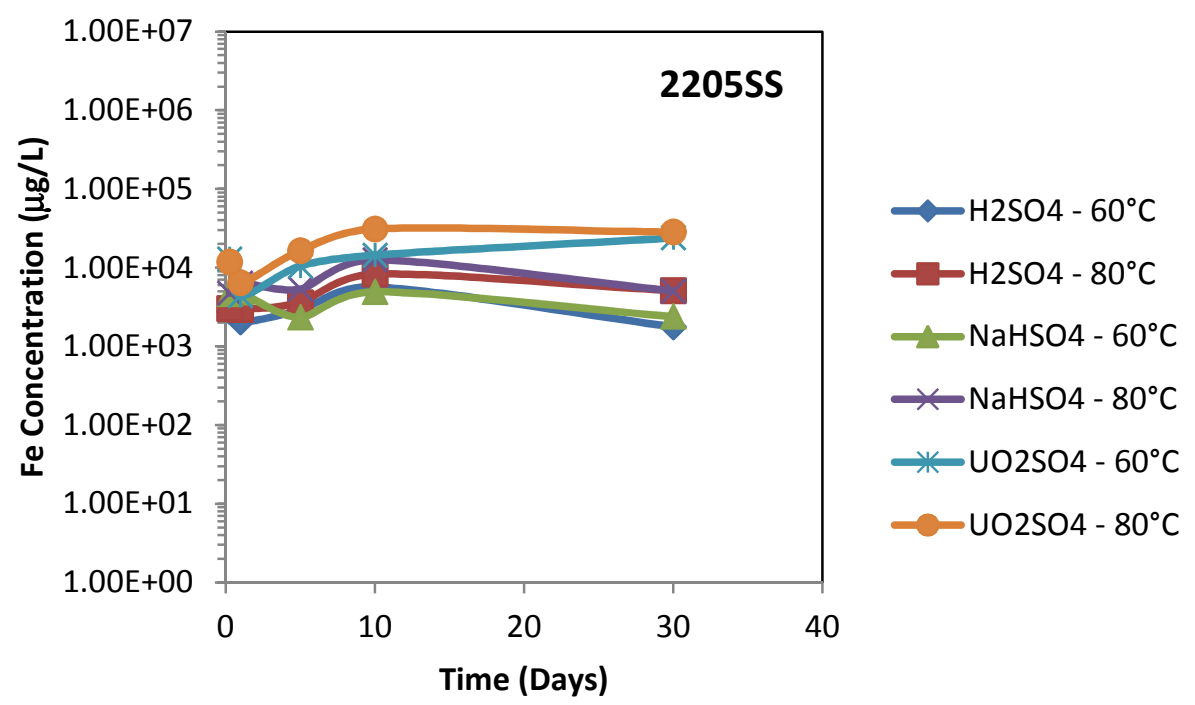

FIGURE 9 Iron Concentration in Various Solutions after Contact with 2205SS Discs for $0.25-30$ Days at $60^{\circ} \mathrm{C}$ and $80^{\circ} \mathrm{C}$

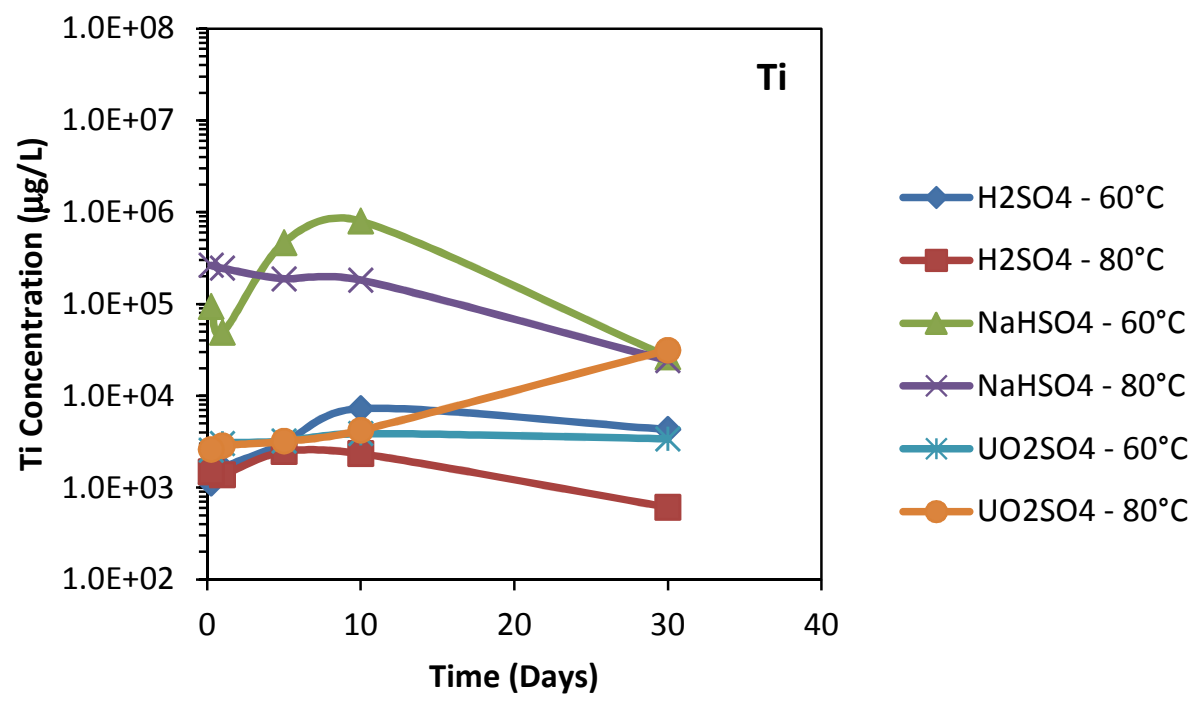

FIGURE 10 Titanium Concentration in Various Solutions after Contact with Ti Discs for 0.25-30 Days at $60^{\circ} \mathrm{C}$ and $80^{\circ} \mathrm{C}$ 
contact with sodium bisulfate solutions at $60^{\circ} \mathrm{C}$ and $80^{\circ} \mathrm{C}$. There is a large increase in $\mathrm{Ti}$ concentration after contact with $\mathrm{UO}_{2} \mathrm{SO}_{4}$ at $80^{\circ} \mathrm{C}$ from $10-30$ days, which indicates that Ti metal may continue to corrode in this type of environment and not form a passivation layer.

Figures 11 and 12 show the Fe concentration present in a $0.1 \mathrm{M} \mathrm{H}_{2} \mathrm{SO}_{4}$ solution at $60^{\circ} \mathrm{C}$ and $80^{\circ} \mathrm{C}$, respectively, after contact with each type of metal disc. Results indicate that the Ti metal has $\mathrm{Fe}$ in it because Fe was present in solution after contact with $0.1 \mathrm{M} \mathrm{H}_{2} \mathrm{SO}_{4}$, and only $28 \mu \mathrm{g} / \mathrm{L}$ was found in the blank acid solution. The 316SS samples had the highest Fe concentration after contact with $\mathrm{pH} 1$ sulfuric acid at $60^{\circ} \mathrm{C}$ and $80^{\circ} \mathrm{C}$. Still, the concentration of Fe in solution for most samples begins to plateau, or even decrease slightly, after 10 days of contact.

Figures 13 and 14 show the Fe concentration present in a $0.55 \mathrm{M} \mathrm{NaHSO}_{4}$ solution at $60^{\circ} \mathrm{C}$ and $80^{\circ} \mathrm{C}$, respectively, after contact with each type of metal disc. Results indicate that the Ti metal has Fe in it because Fe was present in solution after contact with Ti metal, but no detectable Fe was present in the blank sodium bisulfate solution. The 316SS samples have the highest Fe concentration after contact with sodium bisulfate at $60^{\circ} \mathrm{C}$, and at $80^{\circ} \mathrm{C}$, the concentration of Fe present in the 316SS and 304SS samples is almost identical. Still, the concentration of $\mathrm{Fe}$ in solution for all samples levels off after 10 days of contact.

Figures 15 and 16 show the Fe concentration present in a $140 \mathrm{~g}-\mathrm{U} / \mathrm{L} \mathrm{UO}_{2} \mathrm{SO}_{4}$ solution at $60^{\circ} \mathrm{C}$ and $80^{\circ} \mathrm{C}$ after contact with each type of metal disc. The ICP-MS results indicate that the uranyl sulfate solution contains $6.0 \times 10^{4} \mathrm{mg} / \mathrm{L} \mathrm{Fe}$, but the Ti metal also contains Fe based on the corrosion test results with sulfuric acid and sodium bisulfate. The amount of Fe found in the blank solution was subtracted from the amount of Fe found in each sample after contact with uranyl sulfate. As shown in the figures, Fe concentrations increase steadily in all samples over time at $60^{\circ} \mathrm{C}$ and decrease slightly from $10-30$ days at $80^{\circ} \mathrm{C}$, but concentrations never exceed $4.5 \times 10^{4} \mu \mathrm{g} / \mathrm{L} \mathrm{Fe}$.

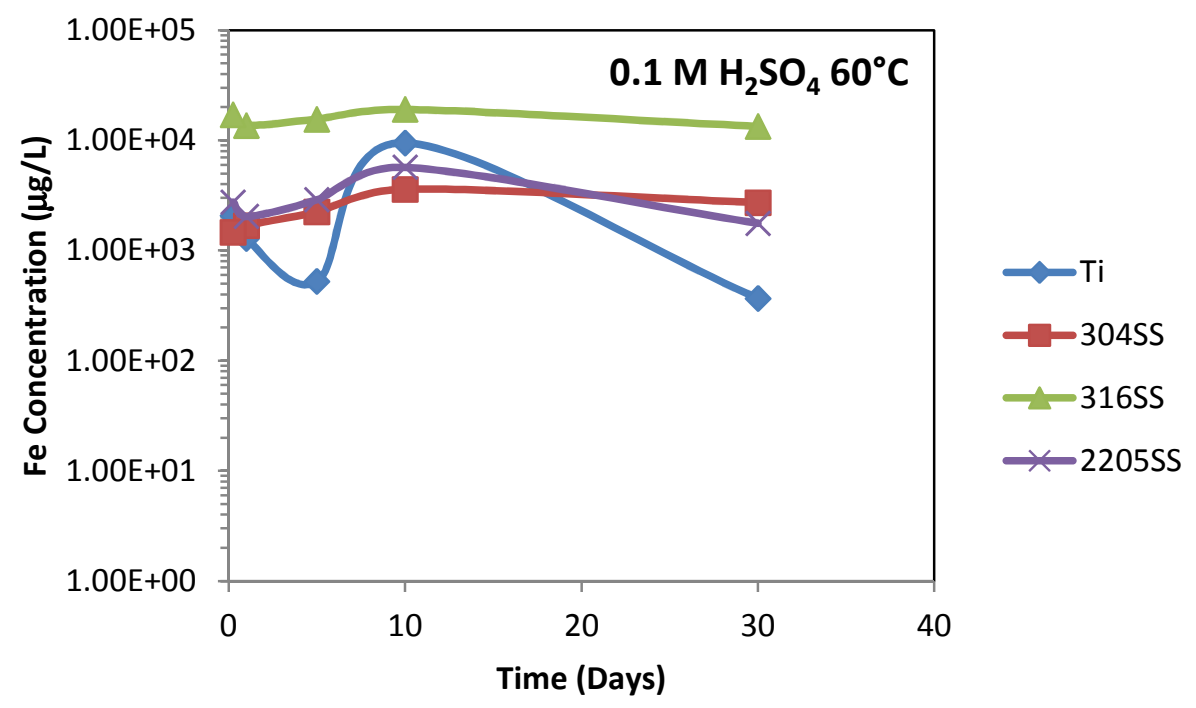

FIGURE 11 Iron Concentration in $0.1 \mathrm{M} \mathrm{H}_{2} \mathrm{SO}_{4}$ Solution after Contact with SS and Ti Dises for 0.25-30 Days at $60^{\circ} \mathrm{C}$ 


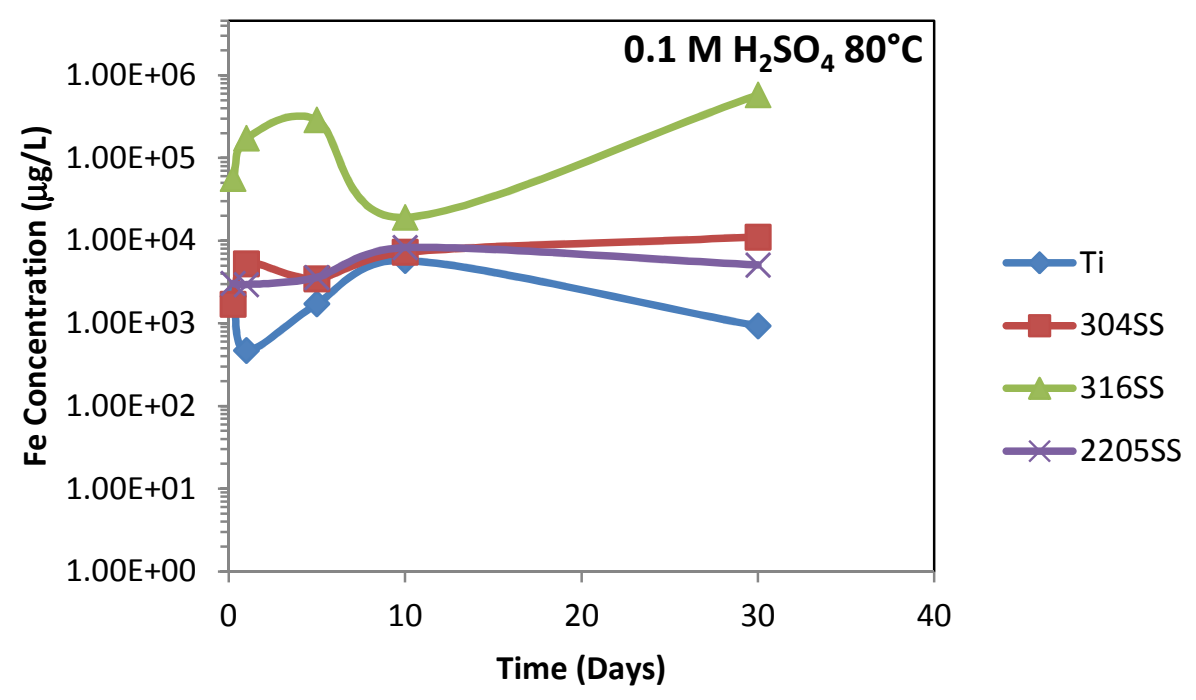

FIGURE 12 Iron Concentration in $0.1 \mathrm{M} \mathrm{H}_{2} \mathrm{SO}_{4}$ Solution after Contact with SS and Ti Discs for 0.25-30 Days at $80^{\circ} \mathrm{C}$

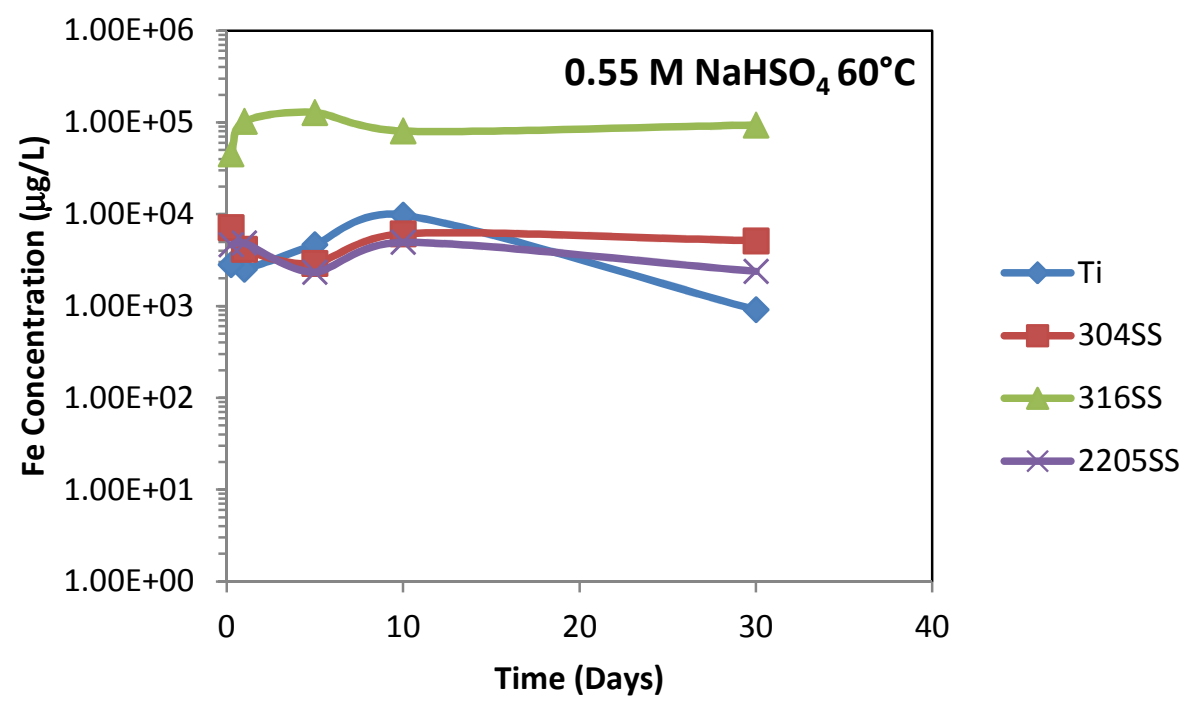

FIGURE 13 Iron Concentration in $0.55 \mathrm{M} \mathrm{NaHSO}_{4}$ Solution after Contact with SS and Ti Discs for 0.25-30 Days at $60^{\circ} \mathrm{C}$ 


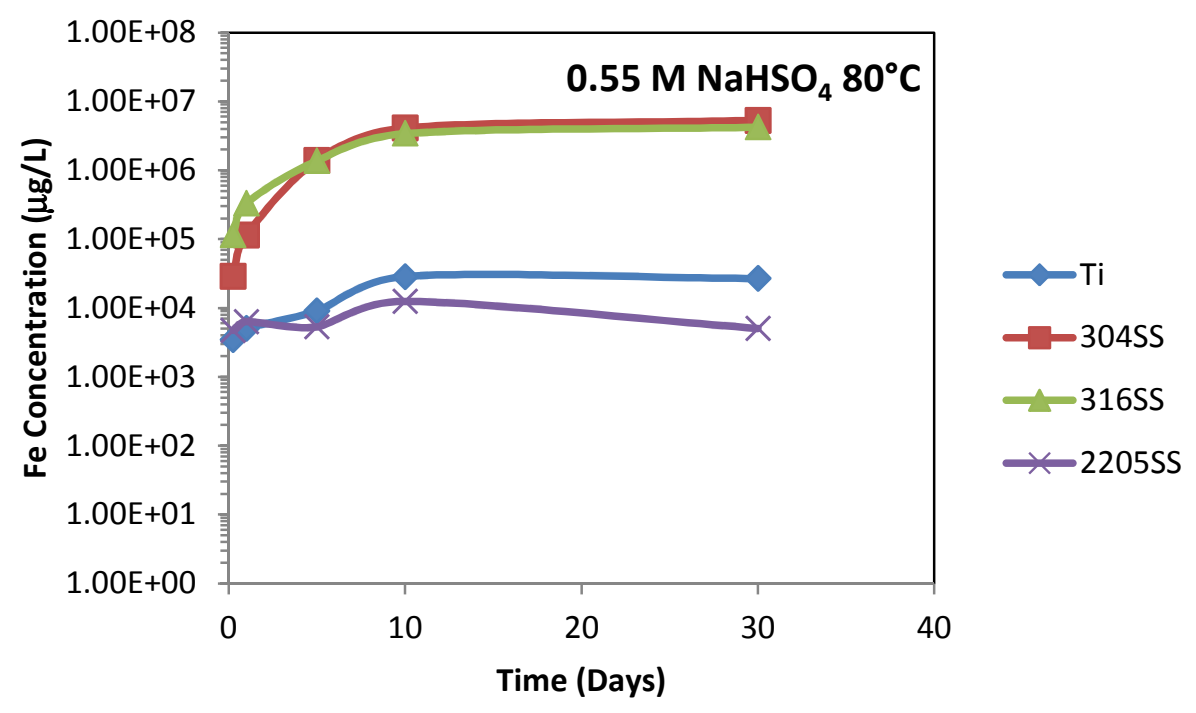

FIGURE 14 Iron Concentration in $0.55 \mathrm{M} \mathrm{NaHSO}_{4}$ Solution after Contact with SS and Ti for $0.25-30$ Days at $80^{\circ} \mathrm{C}$

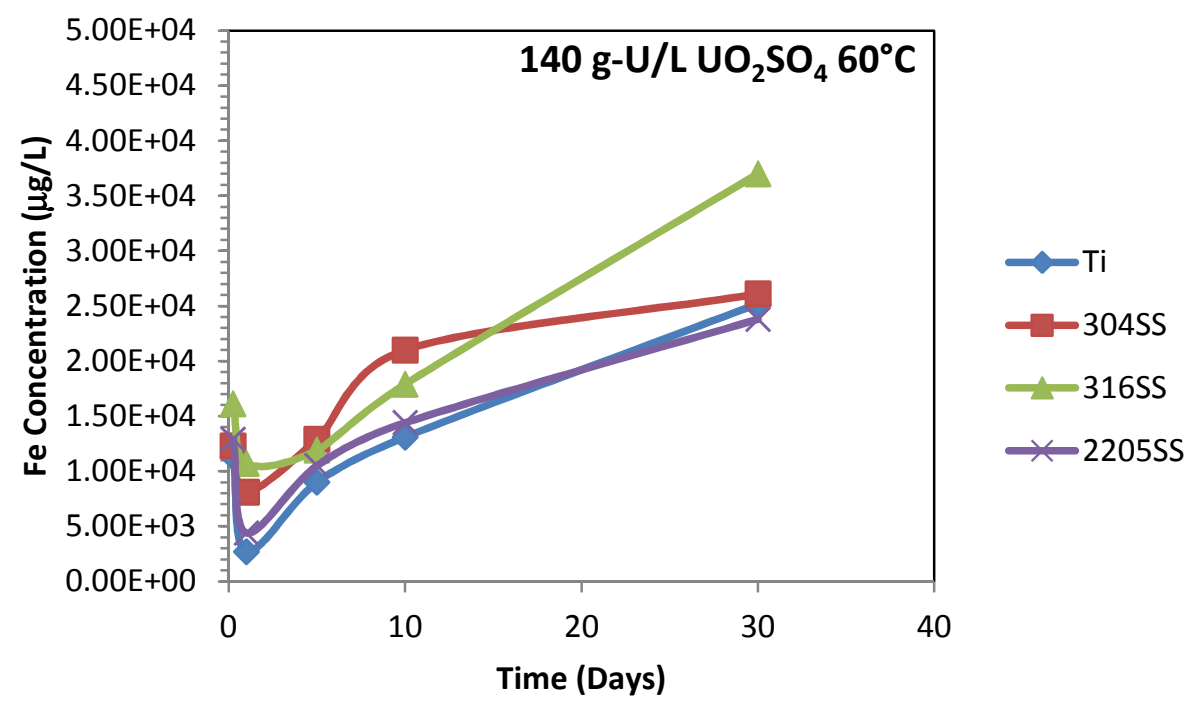

FIGURE 15 Iron Concentration in $140 \mathrm{~g}-\mathrm{U} / \mathrm{L} \mathrm{UO}_{2} \mathrm{SO}_{4}$ Solution after Contact with SS and Ti Discs for 0.25-30 Days at $60^{\circ} \mathrm{C}$ 


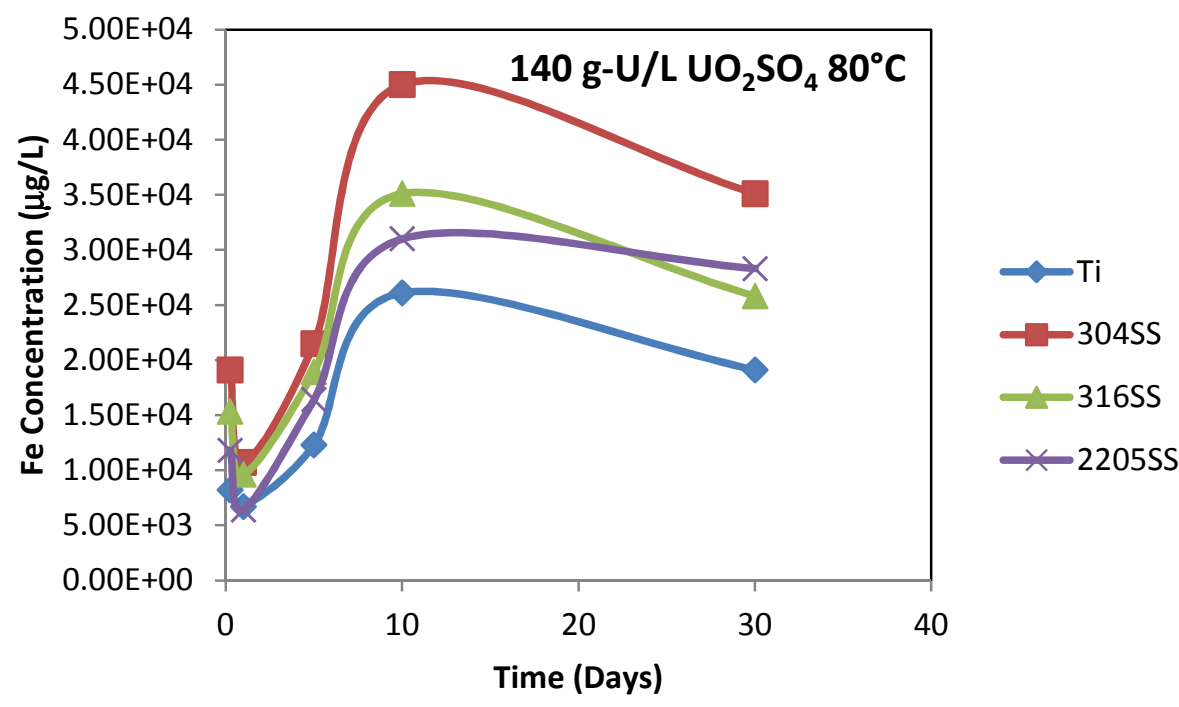

FIGURE 16 Iron Concentration in $140 \mathrm{~g}$-U/L $\mathrm{UO}_{2} \mathrm{SO}_{4}$ Solution after Contact with SS and Ti Discs for 0.25-30 Days at $80^{\circ} \mathrm{C}$ 


\section{DISCUSSION}

The purpose of this set of corrosion tests was to demonstrate to Argonne safety personnel that the mini-SHINE target solution vessel and entire system will not corrode enough to create serious problems. The ICP-MS and mass-change data indicate that the estimated corrosion rates are high at first but decrease to negligible levels once a passivation layer forms. Sodium bisulfate is the most corrosive solution of all those tested because the free sulfate concentration is much higher than in $\mathrm{pH} 1$ sulfuric acid or uranyl sulfate solutions. 


\section{CONCLUSIONS}

Discolored solutions were observed in our mini-SHINE system after it was contacted with $\mathrm{pH} 1$ sulfuric acid and sodium bisulfate solutions. Corrosion tests were performed to assess the stability of the mini-SHINE construction materials, and all results indicate corrosion is not an issue once a passivation layer forms, which usually occurs within the first 24 hours. These results will be useful for SHINE because most of SHINE's plumbing will be 316SS. Corrosion in $\mathrm{pH} 1$ sulfuric acid and uranyl sulfate solutions should not be a problem once a passivation layer forms. 


\section{APPENDIX A}

DATA FOR CORROSION TESTS PERFORMED AT $60^{\circ} \mathrm{C}$ AND $80^{\circ} \mathrm{C}$ IN THE PRESENCE OF 304SS, 316SS, 2205SS, AND TITANIUM 
This page intentionally left blank 


\section{APPENDIX A}

\section{DATA FOR CORROSION TESTS PERFORMED AT $60^{\circ} \mathrm{C}$ AND $80^{\circ} \mathrm{C}$ IN THE PRESENCE OF 304SS, 316SS, 2205SS, AND TITANIUM}

TABLE 1 Data for Discs in contact with $0.1 \mathrm{M} \mathrm{H}_{2} \mathrm{SO}_{4}$ at $60^{\circ} \mathrm{C}$ and $80^{\circ} \mathrm{C}$

\begin{tabular}{|c|c|c|c|c|}
\hline \multicolumn{5}{|c|}{$\mathrm{H}_{2} \mathrm{SO}_{4} 60^{\circ} \mathrm{C}$} \\
\hline $\begin{array}{c}\text { Time } \\
\text { (days) }\end{array}$ & $\begin{array}{c}304 \mathrm{SS} \\
(\mathrm{mm} / \mathrm{yr})\end{array}$ & $\begin{array}{c}316 \mathrm{SS} \\
(\mathrm{mm} / \mathrm{yr})\end{array}$ & $\begin{array}{l}2205 \mathrm{SS} \\
(\mathrm{mm} / \mathrm{yr})\end{array}$ & $\begin{array}{c}\mathrm{Ti} \\
(\mathrm{mm} / \mathrm{yr})\end{array}$ \\
\hline 0.25 & 0.040 & 0.155 & 0.061 & 0.000 \\
\hline 1 & 0.032 & 0.074 & 0.011 & 0.028 \\
\hline 5 & 0.000 & 0.008 & 0.008 & 0.000 \\
\hline 10 & 0.003 & 0.005 & 0.000 & 0.008 \\
\hline 30 & -0.002 & 0.002 & 0.001 & 0.002. \\
\hline \multicolumn{5}{|c|}{$\mathrm{H}_{2} \mathrm{SO}_{4} 60^{\circ} \mathrm{C}$} \\
\hline $\begin{array}{c}\text { Time } \\
\text { (days) }\end{array}$ & $\begin{array}{c}304 \mathrm{SS} \\
(\mathrm{mil} / \mathrm{yr})\end{array}$ & $\begin{array}{c}316 \mathrm{SS} \\
(\mathrm{mil} / \mathrm{yr})\end{array}$ & $\begin{array}{l}\text { 2205SS } \\
(\mathrm{mil} / \mathrm{yr})\end{array}$ & $\begin{array}{c}\mathrm{Ti} \\
\text { (mil/yr) }\end{array}$ \\
\hline 0.25 & 0.002 & 0.006 & 0.002 & 0.000 \\
\hline 1 & 0.001 & 0.003 & 0.000 & 0.001 \\
\hline 5 & 0.000 & 0.000 & 0.000 & 0.000 \\
\hline 10 & 0.000 & 0.000 & 0.000 & 0.000 \\
\hline 30 & 0.000 & 0.000 & 0.000 & 0.000 \\
\hline \multicolumn{5}{|c|}{$\mathrm{H}_{2} \mathrm{SO}_{4} 80^{\circ} \mathrm{C}$} \\
\hline $\begin{array}{l}\text { Time } \\
\text { (days) }\end{array}$ & $\begin{array}{c}304 \mathrm{SS} \\
(\mathrm{mm} / \mathrm{yr})\end{array}$ & $\begin{array}{c}316 \mathrm{SS} \\
(\mathrm{mm} / \mathrm{yr})\end{array}$ & $\begin{array}{l}2205 \mathrm{SS} \\
(\mathrm{mm} / \mathrm{yr})\end{array}$ & $\begin{array}{c}\mathrm{Ti} \\
(\mathrm{mm} / \mathrm{yr})\end{array}$ \\
\hline 0.25 & 0.000 & 0.408 & 0.000 & 0.000 \\
\hline 1 & 0.032 & 0.527 & 0.006 & 0.000 \\
\hline 5 & 0.006 & 0.133 & 0.005 & 0.000 \\
\hline 10 & 0.000 & 0.004 & 0.000 & 0.002 \\
\hline 30 & 0.001 & 0.000 & 0.000 & 0.000 \\
\hline \multicolumn{5}{|c|}{$\mathrm{H}_{2} \mathrm{SO}_{4} 80^{\circ} \mathrm{C}$} \\
\hline $\begin{array}{c}\text { Time } \\
\text { (days) }\end{array}$ & $\begin{array}{c}304 \mathrm{SS} \\
(\mathrm{mil} / \mathrm{yr})\end{array}$ & $\begin{array}{c}316 \mathrm{SS} \\
(\mathrm{mil} / \mathrm{yr})\end{array}$ & $\begin{array}{l}2205 \mathrm{SS} \\
(\mathrm{mil} / \mathrm{yr})\end{array}$ & $\begin{array}{c}\mathrm{Ti} \\
\text { (mil/yr) }\end{array}$ \\
\hline 0.25 & 0.000 & 0.016 & 0.000 & 0.000 \\
\hline 1 & 0.001 & 0.021 & 0.000 & 0.000 \\
\hline 5 & 0.000 & 0.005 & 0.000 & 0.000 \\
\hline 10 & 0.000 & 0.000 & 0.000 & 0.000 \\
\hline 30 & 0.000 & 0.000 & 0.000 & 0.000 \\
\hline
\end{tabular}


TABLE 2 Data for Discs in contact with $0.1 \mathrm{M} \mathrm{NaHSO}_{4}$ at $60^{\circ} \mathrm{C}$ and $80^{\circ} \mathrm{C}$

\begin{tabular}{|c|c|c|c|c|}
\hline \multicolumn{5}{|c|}{$\mathrm{NaHSO}_{4} 60^{\circ} \mathrm{C}$} \\
\hline $\begin{array}{c}\text { Time } \\
\text { (days) }\end{array}$ & $\begin{array}{c}304 \mathrm{SS} \\
(\mathrm{mm} / \mathrm{yr})\end{array}$ & $\begin{array}{c}316 \mathrm{SS} \\
(\mathrm{mm} / \mathrm{yr})\end{array}$ & $\begin{array}{l}2205 S S \\
(\mathrm{~mm} / \mathrm{yr})\end{array}$ & $\begin{array}{c}\mathrm{Ti} \\
(\mathrm{mm} / \mathrm{yr})\end{array}$ \\
\hline 0.25 & 0.000 & 0.614 & 0.225 & 1.417 \\
\hline 1 & 0.011 & 0.353 & 0.000 & 0.159 \\
\hline 5 & 0.009 & 0.071 & 0.000 & 1.700 \\
\hline 10 & 0.000 & 0.015 & 0.006 & 1.493 \\
\hline 30. & 0.000 & 0.007 & 0.000 & 0.002 \\
\hline \multicolumn{5}{|c|}{$\mathrm{NaHSO}_{4} 60^{\circ} \mathrm{C}$} \\
\hline $\begin{array}{l}\text { Time } \\
\text { (days) }\end{array}$ & $\begin{array}{c}304 \mathrm{SS} \\
(\mathrm{mil} / \mathrm{yr})\end{array}$ & $\begin{array}{c}316 \mathrm{SS} \\
(\mathrm{mil} / \mathrm{yr})\end{array}$ & $\begin{array}{l}2205 \mathrm{SS} \\
(\mathrm{mil} / \mathrm{yr})\end{array}$ & $\begin{array}{c}\mathrm{Ti} \\
\text { (mil/yr) }\end{array}$ \\
\hline 0.25 & 0.000 & 0.025 & 0.009 & 0.056 \\
\hline 1 & 0.000 & 0.014 & 0.000 & 0.006 \\
\hline 5 & 0.000 & 0.003 & 0.000 & 0.067 \\
\hline 10 & 0.000 & 0.001 & 0.000 & 0.059 \\
\hline 30 & 0.000 & 0.000 & 0.000 & 0.000 \\
\hline \multicolumn{5}{|c|}{$\mathrm{NaHSO}_{4} 80^{\circ} \mathrm{C}$} \\
\hline $\begin{array}{c}\text { Time } \\
\text { (days) }\end{array}$ & $\begin{array}{c}304 \mathrm{SS} \\
(\mathrm{mm} / \mathrm{yr})\end{array}$ & $\begin{array}{c}316 \mathrm{SS} \\
(\mathrm{mm} / \mathrm{yr})\end{array}$ & $\begin{array}{l}2205 \mathrm{SS} \\
(\mathrm{mm} / \mathrm{yr})\end{array}$ & $\begin{array}{c}\mathrm{Ti} \\
(\mathrm{mm} / \mathrm{yr})\end{array}$ \\
\hline 0.25 & 1.204 & 0.136 & 0.041 & 4.632 \\
\hline 1 & 1.350 & 1.059 & 0.000 & 4.661 \\
\hline 5 & 0.762 & 0.689 & 0.006 & 4.009 \\
\hline 10 & 0.783 & 0.681 & 0.000 & 4.145 \\
\hline 30 & 0.448 & 0.488 & 0.000 & 3.312 \\
\hline \multicolumn{5}{|c|}{$\mathrm{NaHSO} 480^{\circ} \mathrm{C}$} \\
\hline $\begin{array}{c}\text { Time } \\
\text { (days) }\end{array}$ & $\begin{array}{c}304 \mathrm{SS} \\
(\mathrm{mil} / \mathrm{yr})\end{array}$ & $\begin{array}{c}316 \mathrm{SS} \\
(\mathrm{mil} / \mathrm{yr})\end{array}$ & $\begin{array}{l}2205 S S \\
\text { (mil/yr) }\end{array}$ & $\begin{array}{c}\mathrm{Ti} \\
\text { (mil/yr) }\end{array}$ \\
\hline 0.25 & 0.047 & 0.005 & 0.002 & 0.182 \\
\hline 1 & 0.053 & 0.042 & 0.000 & 0.183 \\
\hline 5 & 0.030 & 0.027 & 0.000 & 0.158 \\
\hline 10 & 0.031 & 0.027 & 0.000 & 0.163 \\
\hline 30 & 0.018 & 0.019 & 0.000 & 0.130 \\
\hline
\end{tabular}


TABLE 3 Data for Discs in contact with $140 \mathrm{~g}-\mathrm{U} / \mathrm{L} \mathrm{UO}_{2} \mathrm{SO}_{4}$ at $60^{\circ} \mathrm{C}$ and $80^{\circ} \mathrm{C}$

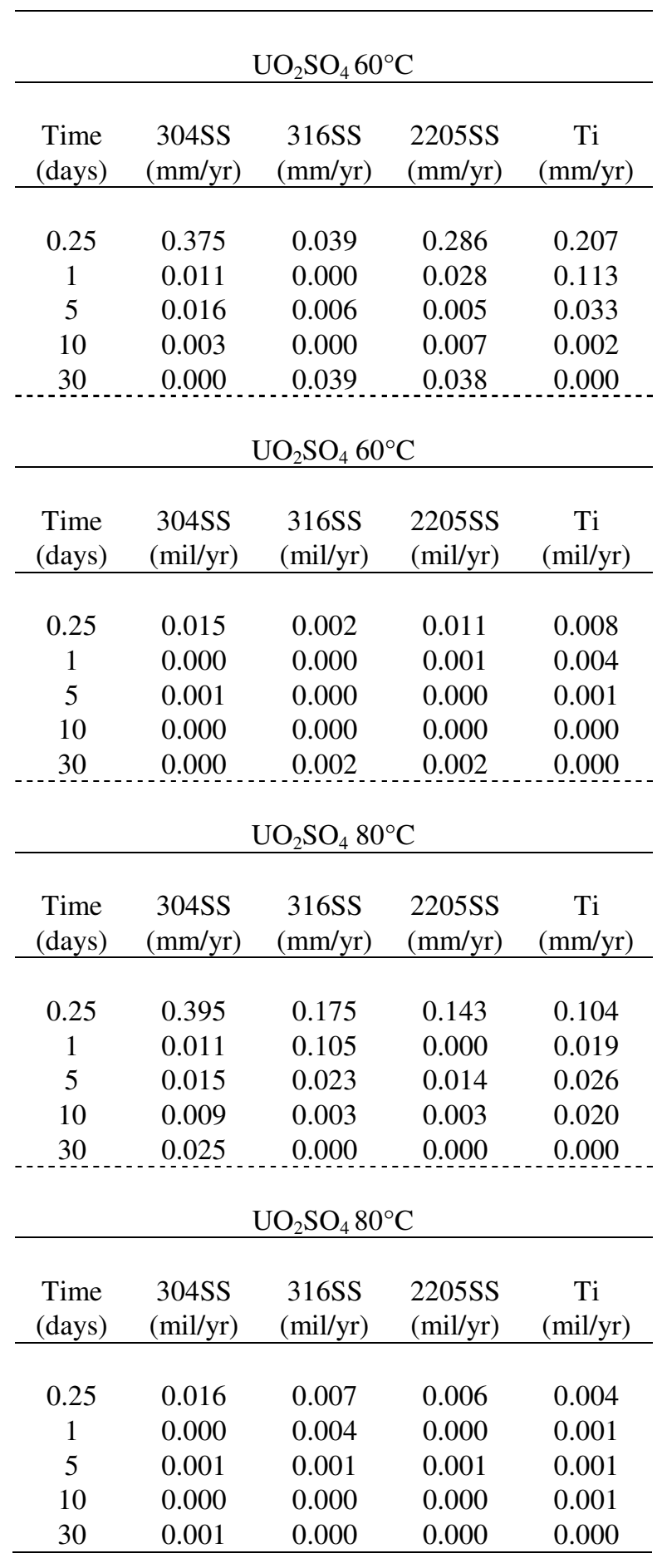


This page intentionally left blank 



\section{Argonne}

Chemical Sciences and Engineering Division

Argonne National Laboratory

9700 South Cass Avenue, Bldg. 205

Argonne, IL 60439-4837

www.anl.gov

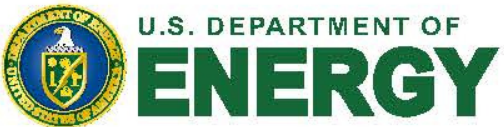

Argonne National Laboratory is a U.S. Department of Energy

laboratory managed by UChicago Argonne, LLC 